\title{
Learning Design of Combinatory Using Indonesian Realistic Mathematics Education
}

\author{
Somakim \\ Mathematics Department \\ Sriwijaya University \\ Palembang, Indonesia \\ Somakim_math@yahoo.com
}

\author{
Darmawijoyo \\ Mathematics Department \\ Sriwijaya University \\ Palembang, Indonesia
}

\author{
Ning Eliyati \\ Mathematics Department \\ Sriwijaya University \\ Palembang, Indonesia
}

\begin{abstract}
This study aims to find out how the use of Indonesian realistic mathematics education approach (PMRI) can support students' understanding in learning the concept of combinatory. The research method used is Design research. Design research consists of three stages: preliminary, teaching experiment and retrospective analysis. Data collection techniques obtained through video recording, student worksheets, pre-test, post-test, field notes and interviews. The subject of the research is the students of Senior High School 15 Palembang. Data analysis techniques are done by comparing the HLT that has been designed and what happens during the learning process. The results show that PMRI with role playing context can support students' understanding in finding combinatory concept, especially permutation and combination topics.
\end{abstract}

\section{Key word-PMRI, Combination, Role Playing context}

\section{INTRODUCTION}

Combinatory is one of the topic of mathematics in high school. According to the 2013 curriculum of Indonesia, it includes permutation and combination materials. As we know that mathematics is abstract so math subjects are perceived and difficult for most students [4]. Therefore, it is necessary a certain method or model of learning so that students can follow the lesson with the feeling of enjoying so as to generate more confidence of students. Mathematical permutations and combinations are matter

Combinatory is the important topic for students majoring in science and social studies. The combinatorical material consists of the subject of Permutations and Combinations [15]. The learning process of combinatorics material is done with the design of learning by enumeration [14].

Role-play learning is one of the model in PMRI Mathematical learning by using role play in accordance with the philosophy of PMRI that is Mathematics is human activity [9]. Implementation of PMRI can improve students' ability in problem solving, critical thinking, conceptual understanding [16] [24] [25]

The application of PMRI is also in line with the learning objectives in the Curriculum 2013 which is student's engagement through scientific activities [15]. The choice of research by using instructional design can increase student activity and involvement in learning [11][19][22].

Context in PMRI is the early step in learning design to build students' knowledge about the mathematics concepts because context related to specific situation and can emerge the environment that involves students. According to Troffers and Goffered, that role-play context as a tool for forming the concept (concept forming). Role-play is selected as a context in learning combinatorics, especially permutation and combination because thiscontext often encountered in life stud ents. Based on classification of context, role-play could have inserted to personal context of students. As an introduction in learning process, role-play context, student more first doing learning multiplication over and over factorial After activities apperception held then students requested for forming groups that have arranged such.as likene ss by teachers and doing learning permutation and combinations with use context play the role of the theme election chairman, and vice chairman in OSIS stewardship a nd many people shook hands. Students requested write how many possibility occurrence form team stewardship and shake that happened student activity sheets that have been designed and provided by researchers and model teachers.

\section{METHOD RESEARCH}

This research is using design research method which is one of the qualitative approach. Design research aims to develop Local Instruction Theory (LIT) based on an existing theory) and empirical experiment through cooperation between researchers and teachers to improve the relevance of research to policy and practice of education [10], There'sthree stages in the design of research are: preparing for the experiment, the experimental design and analysis the retrospective [5]. The point of this study is the assumption of learning in the classroom with HLT design so as to produce the learning trajectory. The HLT are analyzed and redesigned and revised and then implemented again.

This suggests that there is a recurrent process cycle from thought experiment to the learning experiment (instruction experiment ) [9]. The cycle process can be seen as shown by Figure 1. 


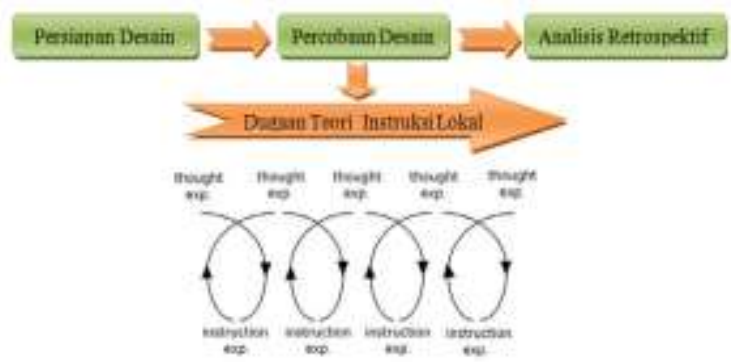

Fig 1. Design Research Cycle

Subjects involved in this study were the students of class X SMA N 15 Palembang and a teacher in the classroom as the teacher models and implemented in the first semester of the academic year 2017/2018. Data collection techniques used in this study are tests, verbal observation, and interviews, and questionnaires. Early and late mathematics, observation, and interview skills are part of qualitative analysis techniques for the research design section.

\section{RESULTS AND DISCUSSION}

This research resulted the trajectory of learning for permutation using class management election context, and combinations using students'handshake contexs. Reseacrh conducted in SMA N 15 Palembang with 6 students from grade X IPA 1 for pilot teaching implementation, and 36 students from grade X IPA- 3 for the teaching experiment. There are three stages in this research, namely preliminary design, the design experiment and the retrospective analysis. At the stage of preliminary design, the researchers designed the Hypothetical Learning Trajectory (HLT) permutation using context play a role in the election of board Osis, is selecting the chairman and deputy in the Sheet Activity Students (LAS) 1, whereas the combination by using the context of the play shaking hands on LAS 2. HLT was further tested on experimental design phase includes two phases, pilot experiments and teaching experiment. After the teaching experiment stage is completed, the researcher retrospective analysis of what has been obtained in the previous stage and described in discussion section.

On LAS 1 permutation material, the given problems is " Determine the number of osis board composition that is chairman and representative that can be formed from three, four, and five people. "Figure 2 is a student activity when presenting the results of the discussion .

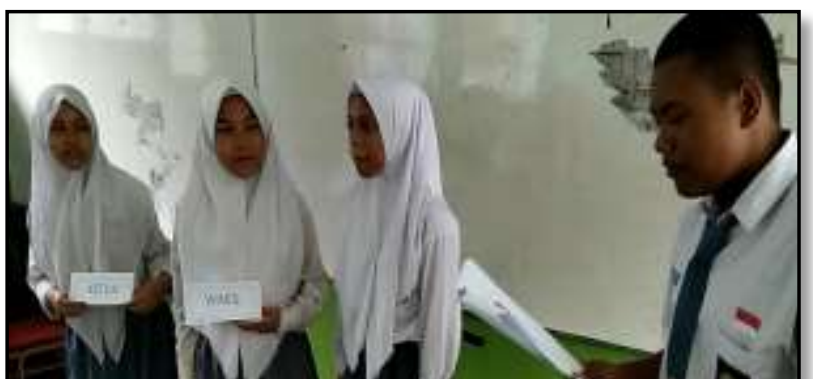

Fig 2. Student activity when presenting the results of the discussion
After the students perform role-play activities on the selection of osis board consisting of chairman and representatives of groups of students consisting of three, four and five students, then they fill the LAS. Then the group of students discussed to fill the LAS. The result of one group discussion is presented in Figure 3.

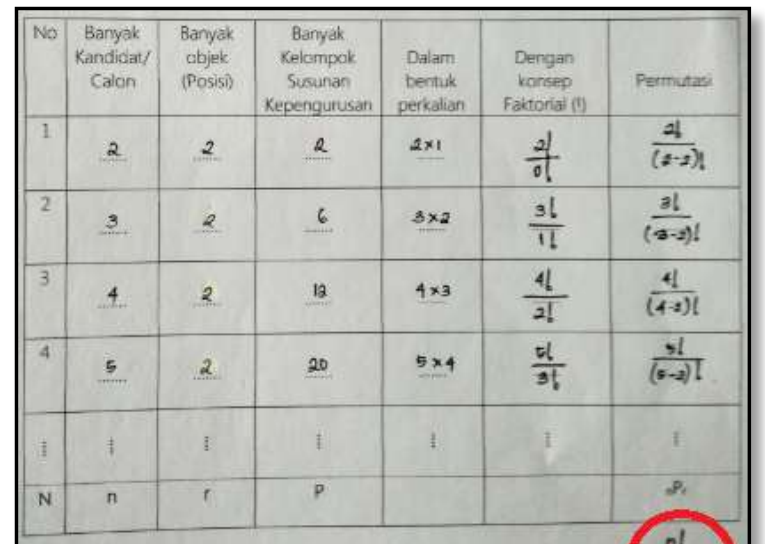

Fig 3. The result of one group discussion

Meanwhile, LAS 2 is an activity for the material combination of activities. As well as the activities of permutations material, the second activity begins with the instrumental activities with the students shook hands with each other, which started with a group of three students, followed by four students, and the last with five students.

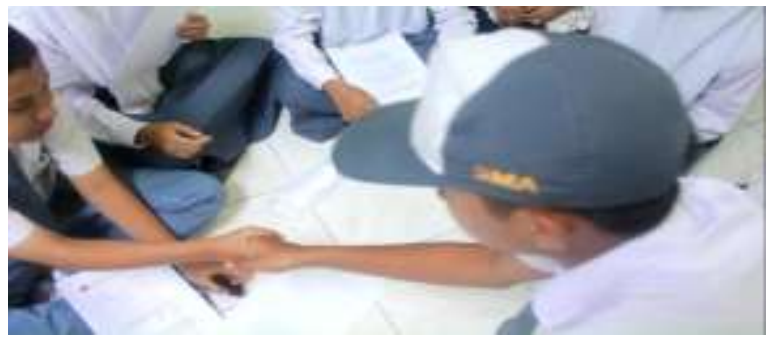

Fig 4. Student activity in shaking hands as a context to find the concept of combination.

After completion of the role-play activities, it is followed with the discussion activities to fill the LAS result from many shakes and subsequently deflected in LAS, as in Figure 5.

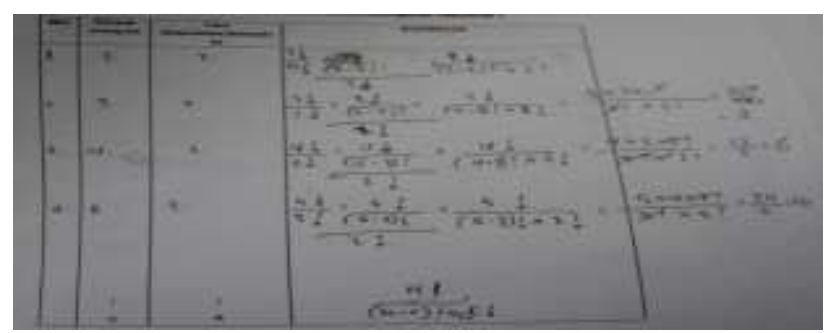

Figure 5. The result of one group discussion 
This research is using role play activity. B role in this research is to play something and then arrange or select it on certain rules of available actors related to shake that is implemented through the activity of selecting some object from all available object. Therefore, students do "election" activities related to the combination directly, not just imagine it. In addition, colored paper used helps students in understanding the meaning of combinations. All the different colored papers represent the whole object and the student selects some colored paper as his experimental way. With colored paper it helps students in mathematical modeling from the given activities.

The developed learning design of combinatorics is a lesson based on PMRI implementation, in designing each combinatorial learning activity showing how the characteristics of PMRI become the basis for each activity. Reference [28] mentions 5 characteristics of PMRI namely the use of context, the use of model, contribution and construction, interactivity or linkage. The following will explain the relationship of five characteristics of PMRI in this combinatorial learning.

In Activity 1, the learning activity begins with the user of a contextual problem experienced by the student. In this research use role play context to determine the many form of arrangement that may occur from selection of OSIS stewardship ie chairman and representative of OSIS for permutation material, while role playing activity shake hands for material combination. Through this activity students are able to understand what permutations and combinations in which the first thing students do is to determine how many possible forms of management may occur from 2 candidates / nominees and OSIS representatives, from 3 candidates / nominees and vice-presidents, and from 4 candidates / nominees and OSIS representatives. These activities give different things to the students because all students can get involved in the lesson so that the learning is more meaningful.

Next the second characteristic is the use of the model. According to [9], there are 4 different levels in RME, situational,

model of, model for, and formal . In activity 2, a large number of groups formed from OSIS candidate selection may be from 2 candidates / candidates, from 3 candidates / candidates, from 4 candidates / candidates, and from 5 candidates or candidates is a form of the second level ie model of . Furthermore, the form of the number of arrangements of management groups formed to be converted to the closest keperkalian form and change the form of the closest multiplication into a form of factorial concept, it has entered the level model for. Then, from the form of the factorial concept the students are asked to define the general pattern of permutations, this is already a formal level. Furthermore on the activity of 3 students make use of the common pattern they have found to solve the problems of permutations related to daily life.

The third characteristic is contribution and construction. This is seen in the process of learning implementation of each activity both during the execution of cycle 1 and when the implementation of cycle 2, where the teacher highly appreciate every answer and student contribution that emerged during the learning process took place. Teachers give students the freedom to express and answer questions in their own way according to their knowledge, as seen from their reasons for answering each question. The teacher as a facilitator directs the students to discuss in solving any problems that exist on the Student Activity Sheet (LAS) that is given.

The fourth characteristic is interactivity, in the learning process bail on learning cycle 1 and learning cycle 2, interactivity not only happened between teacher and student but also happened with fellow student, this seen at all transcript of conversation both student discuss together with member of group at when solving existing problems or transcripts of teacher conversations with students during the process of mentoring.

The last characteristic is linkage. In this permutation study cannot be separated from factorial concept, multiplication rules, division rules, and reduction rules. Students who have a good knowledge of the material will feel easier when completing every activity there. Based on the results of research and retrospective analisys that have been done, this learning is designed to produce learning paths to assist students in learning the material combinations using a handshake context.

Implementation of PMRI implementation using role play context is also in line with demands of revision 2017 curriculum activities focusing on character formation, literacy, and competence. The formation of character is seen from the students themselves in terms of responsibility, confident, and honest in performing role playing activities. Literacy skills can be seen in the ability to express opinions both in group discussions and during presentations in front of the class. While the ability of competence, it can be seen from the students' result of learning materials (LAS), groups of students are able to discover combinatorial concepts (permutations and combinations).

\section{CONCLUSION}

Based on the results and discussion, it can be concluded that using PMRI, the Indonesian version of Realistic Mathematics Education approach, particularly the role-play context as an activity based experience has help students to understand combinatorial concepts, especially in permutations and combinations.

\section{ACKNOWLEDGMENT}

This research is funded by Sriwijaya University. Thanks to School- principal of SMA N 15 Palembang to the permission for collecting the data.

\section{REFERENCES}

[1] J. Clerk Maxwell, A Treatise on Electricity and Magnetism, 3rd ed., vol. 2. Andresen, M. Introduction of new Construct: The Conceptual Tool "Flexbility". The Montana Mathematics Enthusiast, Vol. 4, No. 2 pp.230-250. (2007).

[2] Arends. RILearning to Teach. $6^{\text {th }}$ Edition. Boston: Mc Graw Hill ( 2004). . 
[3] Armanto, D. Aspect Change Education Basic through Realistic Mathematic Education(PMR). Paper be delivered at the National Seminar Day : Implementation Realistic Mathematics Education on School and Madrasah, November 5, 2001, Medan : No Published. (2001).

[4] Armanto, D. Teaching Multiplication and Division Realistically in Indonesian Primary Schools: A Prototype of Local Instructional Theory. Thesis University of Twente. Enschede : Print Partnersipskamp Press. (2002).

[5] Bakker, A. History and Didactical Phenomenology of the Average Value. CD-Rom in Brochure for the $9^{\text {th }}$ International Congress on Mathematics Education (ICME9) in Japan, July 2000. (2000).

[6] BAP-

S/M. (2008). Directory Results Accreditation School /Madrasah Year 2 005 - 2008. Palembang: BAP -S / M.

[7] Drajat Friansah, Zulkardi, Somakim . . Development of Teaching Materials Based on Cabri 3dmateri Dimension Three Class XS MA . Journal Elements Vol. 1 No. 2, July 2015, p. 1 - 12 . 2015

[8] Feijs, Els. Conctructing a Learning Environment that Promotes Reinvention. Freudenthal Institute. CD-Rom in Brochure for the $9^{\text {th }}$ International Congress on Mathematics Education (ICME9) in Japan, July 2000.

[9] Gravemeijer , Koeno . Developing Realistic Mathematics Education. Utrecht: CD-b Press. The Netherlands. (1994).

[10] Gravemeijer , Koeno . Developmental Research: Fostering a Dialectic Relation between Theory and Practice. Freudenthal Institute . CD-Rom in Brochure for the $9^{\text {th }}$ International Congress on Mathematics Education (ICME9) in Japan, July 2000.

[11] Hariani Juwita, Ratu Ilma Indra Putri, Somakim. 2015. Journal of Elements. Journal Elements Vol. 1 No. 2, July 2015, p. 53-66.

[12] Hadi, Sutarto, Tjeerd Plomp \& Suryanto . (2002). Introducing Realistic Mathematics Education to Junior High School Mathematics Teacher in Indonesia. Proceedings of $3^{r d}$ International Mathematics Education and Society Conference. Copenhagen: Center for Research in Learning Mathematics, pp. 5-16

[13] . Education Mathematics Realistic and Implementation . Banjarmasin: Banjarmasin . (2005)

[14] Iis Juniati, Lathiifah , Zulkardi , Somakim (2015). Development Teachin g Material Material Rules Enumeration UsingLearning Based Problem i n SM A. Journal Didactic Math. Vol. 2, No. 2, September 2015.

[15] Kemendikbud Curriculum 2013 Standard Content of Mathematics Subjects. Jakarta(2013).

[16] Kesumawati, Nila Improved Ability of Understanding, Problem Solving, and Mathematical Disposition of Students S MP Through Realistic Approach to Mathematics Education . Dissertation. UPI(2010) .

[17] Kwon ON Conceptualizing The Realistic Mathematics Education Approach in The Teaching and Learning of Ordinary Differebtial Equations. Eurasian Journal of Mathematics, Science and Technology Education Volume 2 Number 2, July 2006. (2010)

[18] Lange, Jan de .. Assessment: No Change Without Problems. The Netherlands: Freudenthal Institute. (1996).

[19] Marion, Zulkardi, Somakim Design of Learning Pattern Numbers Using the Model of Profit Net at SMP. JOURNAL OF EDUCATION, Volume 45, Number 1, May 2015, Page 44-61 ( 2016 )

[20] Sabandar, J Think Reflective . Paper presented at National Seminar Day: Per Mathematical Problems and Mathematics Education Date 8 December 2007 , UPI Bandung : Not Published. . (2007).

[21] Contextual Aspects in Mathematics Learning . Paper presented at National Seminar Day: Implementation of Realistic Mathematics Education at School and Madrasah, 5 November 2001, Medan: Not Published. (2001).

[22] Sari Saraswati, Ratu Ilma Indra Putri, Somakim ( 2016 ) . Supporting Students' Understanding Of Linear Equations With One Variable Using Algebra Tiles. Journal on Mathematics Education, Volume 7, No. 1, January 2016, pp. 21-31.

[23] Soedjadi, R. PMRI and KBK in the Era of Education Autonomy . PMRI Bulletin . Issue III, Jan 2004. Bandung: KPPMT ITB(2004).
[24] Somakim Improving the Ability of Critical Thinking and Mathematical Self-Efficacy of Junior High School Students Using Realistic Mathematical Approaches . Dissertation. UPI. (2010).

[25] Sugiman Impact of Realistic Mathematics Learning on Improving Problem Solving Ability and Mathematical Beliefs of Junior High School Students in Yogyakarta City . Dissertation. UPI. (2010).

[26] Whitehead, Paul. Teaching and Learning with RME . [ online ] Available : http://partnership.mmu.ac.uk/cme/Student_ Writing/TS1/PaulWhitehead.html . Retrieved : March 6 , 2008 . (2004).

[27] Yayan Eryandi, Somakim, Yusuf Hartono . Learning Materials Design Pattern Numbers Context Making Kemplang In Class IX. Journal on Mathematics Education, Volume 7, No. 2, July 2016, pp.45-52( 2016 )

[28] Zulkardi RME an Innovation in Education Mathematics in Indonesia. Pa per be delivered at the 10th KNM at ITB: No published . (2000). 